Sogial Policy \& Administration issn oi $44-5596$

Vol. 35, No. 5, Degember 200i, PP. 559-568

\title{
People, Land and Sustainability: \\ Community Gardens and the Social \\ Dimension of Sustainable Development
}

\author{
John Ferris, Garol Norman and Joe Sempik
}

\begin{abstract}
Community gardens vary enormously in what they offer, according to local needs and circumstance. This article reports on research and experience from the USA. The context in which these findings are discussed is the implementation of Local Agenda 21 and sustainable development policies. In particular, emphasis is given to exploring the social dimension of sustainable development policies by linking issues of health, education, community development and food security with the use of green space in towns and cities. The article concludes that the use of urban open spaces for parks and gardens is closely associated with environmental justice and equity.
\end{abstract}

\section{Keywords}

People; Land; Community gardens; Sustainability; Green space; Poverty; Food security

\section{Introduction}

This article is dedicated to the memory of Maylie Scott, who died of cancer on Io May 200I. Maylie Scott was an outstanding exemplar of a new generation of Zen Buddhist women priests. Her courage and qualities of leadership were outstanding and renowned among social activists in the San Francisco Bay area. Maylie's life and actions have inspired whatever merit this article about the role of community gardens, and we must say the role of women, may have in helping to make our cities environmentally and socially more civilized places in which to live and work. Maylie's life, as a Buddhist, was dedicated to helping all living things. There was no distinction between natural and human interests. At the centre of this vision is an image of all life forms being deeply interconnected.

Address for correspondence: Fohn Ferris, c/o PLS, Humanities Research Unit, Old Engineering Building, University of Nottingham, University Park, Nottingham, NGg IDQ. 


\section{Research Aims and Objectives}

The research that underlies this article was carried out in the USA at various times during the I99os: first in Pennsylvania and then in the San Francisco Bay area. The research in the United States was exploratory and aimed at identifying the possible relevance of US experience to urban regeneration and community development policies in the UK. The first step was to survey the range of community gardens and develop a loose typology of the forms and types of garden and, by means of interviews, to establish the range of purposes intended by those involved. The research was policy-orientated in that we sought to gather information that might be useful to local community groups and municipalities as part of Local Agenda 2I and efforts to promote sustainability in urban areas. Would it be possible to replicate initiatives developed in a North American context in Britain, with different governmental, legal and cultural values? As one of the researchers was an occupational therapist with a strong interest in healing and therapy gardens, this became an important dimension in the research.

\section{People, Land and Sustainability Conference, Nottingham, 2000}

An important part of this exploratory research process was the organization of an international conference in Nottingham in September 2000. Although the primary purpose of the conference was aimed at raising the profile of community gardening and its contribution towards global sustainability, a secondary aim was to gather more information about community gardening. Thus the conference report was both promotional and an interim product of an ongoing research process. An informational and promotional video film was another outcome of the conference. An interactive website will be set up before the end of $200 \mathrm{I}$ (see Ferris et al. 200I).

\section{What Is a Community Garden?}

What distinguishes a community garden from a private garden is the fact that it is in some sense a public garden in terms of ownership, access, and degree of democratic control. Community gardens exist in many nations and in both urban and rural areas. They vary in what they offer according to local needs. Some provide open space and greenery. Sometimes they provide cheap vegetables for a local community. With the spread of cities and consequent land scarcity, the demand for communal gardens seems to be increasing. Community gardens are now recognized to be an international phenomenon, and urban gardening is widely seen to be a way of improving local food supplies as well as leisure and recreational activity. This was publicized very widely by the UN Urban Habitat Conference held in Instanbul in 1996.

At the Nottingham conference a wide range of perspectives on community gardening was gathered together in a way that was intended to promote a very broad and inclusive vision of community gardening. It is not very useful 
to offer a precise definition of community gardens as this would impose arbitrary limits on creative communal responses to local need. The contributions to the conference were organized under five main headings:

- Gardening in the Community

- Gardening and Health

- Children and Gardening

- Food Security

- Reclaiming the Land

The idea underlying this way of organizing the contributions was that the conference would seek to highlight the social dimension of sustainability. The themes were community, health, children, food security and poverty. We also wanted to make the case for recognizing the need for public green spaces in our urban settlements. We contend that the concept of community gardens should be very broadly conceived to include many kinds of civic intervention with local governments and other public agencies acting in partnership with citizen groups of various kinds. What is now very evident is that the environmental issues discussed at the UN conference held in Rio de Janeiro in 1992 (see Environmental Politics 1993) are demanding common responses from local communities globally. Food security and access to open green space for recreation are by no means the least of these. Community is a protean concept and can take many forms and serve diverse interests. We should expect community gardens to reflect this pluralism and diversity. All the types of garden referred to here serve, in our view, to contribute to the objective of promoting environmental justice by reconciling people, land and sustainability. This is what the Nottingham conference in September 2000 was about (Ferris et al. 200I).

\section{Community Gardens in the San Francisco Bay Area}

In this section we consider the question of what a community garden is by reporting on research carried out in the summer of 1997 in the San Francisco Bay area. A loose classification and characterization of community gardens emerged from our research. We were satisfied that most of the forms of gardening activity that we were able to see could be found in other North American cities and, indeed, in other nations worldwide. The list that emerged is not definitive but does, we feel, cover most of the kinds of garden we were able to visit in the San Francisco Bay area:

- Leisure gardens

- Child and school gardens

- Entrepreneurial gardens

- Crime diversion gardens/Work and training gardens

- Healing and therapy gardens/Quiet gardens

- Neighbourhood pocket parks 
- Ecological restoration gardens/parks

- Demonstration gardens

These labels are not mutually exclusive and gardens can often combine more than one of these functions. What all of these gardens have in common is the fact that specific communities actively support them. Frequently, but not invariably, they are supported by charitable or municipal grant aid. They all reflect in some way mutual aid and forms of communal reciprocity. It is also quite likely that there will have been a fair degree of altruism in getting them started. It is this complex of motivations that makes it appropriate to call them community gardens. Although community gardens do have a long history there is no doubt that they have been given a fresh impetus by the emergence of international concern with the environment and sustainability. Local Agenda 2I, agreed at the UN Conference on the Environment held in Rio de Janeiro in June i992, placed great emphasis on sustainable development at the local level (see Roddick and Dodds I993).

Urban regeneration policies increasingly tend to include some provision for community involvement in green space planning. Advocacy for more sustainable cities includes advocacy for access to land for local community purposes, especially recreational space and for food growing.

\section{Leisure gardens}

Perhaps the most common type of garden to be found in the Bay area and in most other cities is the recreational or leisure garden. In the San Francisco area these are usually organized for a neighbourhood with a relatively high proportion of apartment-dwellers and people without gardens. These gardens typically contain between 20 and 50 small plots where gardeners grow flowers and vegetables by intensive deep-bed methods. There is also likely to be a picnic/barbecue space and a communal tool shed. The plots are about ıo $\times 20$ feet. The whole area would be enclosed by a chain link fence and secured gate. Such gardens are tended very zealously and reflect great cultural diversity in terms of plants and vegetables that are grown. Residents have often taken over neglected urban sites that were occupied by teenage gangs and drug dealers. For example, many of the New York gardens were built on vacant lots that were left empty and derelict by the New York City Council. They were in effect squatted by local community activists so as to create additional green space and to create gardens for flower and vegetable growing (see Ferris et al. 200I).

\section{Child and school gardens}

In California school gardens are very popular and are actively promoted by the State Education Department with slogans like "a garden in every school". The Le Conte Elementary School on Russell Street, Berkeley, is a very good example. This is a multicultural school with pupils from very diverse backgrounds. The garden, which has flowers and vegetables, also has livestock 
such as goats, sheep and chickens. It offers many activities, which involve children and parents. The science curriculum is integrated with a wide range of garden activities like propagation, transplanting, harvesting, composting and soil preparation. This garden project has been fully supported by the head teacher and developed by a technician, Ms Jackie Omania, who has a degree in environmental science.

Another example of a lively school garden is the Edible Schoolyard at Martin Luther King Junior High School in Berkeley (Ferris et al. 2001: 35). Like Le Conte this school aimed to integrate the activities of the garden with elements of the curriculum. The most innovatory aspect of the Edible Schoolyard is that it sought to implement a vision of a garden growing food for the kitchen. The students at the School built and maintained the garden. One acre of derelict land was transformed into a beautiful and productive garden. The founder of the Edible Schoolyard was Alice Waters, the widely celebrated chef who is the founder of the home of California cuisine, the restaurant Chez Panisse in Berkeley. Alice Waters is a passionate advocate of both organic food production and good cooking of fresh vegetables (see Waters i996; Ferris et al. 200i).

Perhaps the most impoverished community in the Bay area is North Richmond, an area with a mostly non-white population. The Verde Elementary School, which is Ioo per cent non-white and in the midst of an impoverished community, was clearly living on the margins in 1997. A garden was created and maintained at the school by Mien hill people who were refugees from Laos in the mid-I970s. This garden was one of the most productive we saw in California. The Mien women simply recreated the kind of garden they would have grown at home using iron-age methods and tools. Supporting the teachers was a volunteer master gardener and a volunteer child psychologist, Cassie Scott, who worked closely with preschool children who came along with their mothers to the garden as well as older children experiencing difficulties in class. The garden was the platform for a wide range of educational activity as well as vegetable production.

There were numerous other school garden projects in the San Francisco Bay area and this was clearly a growing area of community garden activity. It should be stressed here that the garden activity reached out into the community through parental involvement in these gardens.

\section{Entrepreneurial gardens}

Another type of garden that we visited in California can best be described as entrepreneurial. The purpose of these gardens is diverse, but is clearly driven by the need to alleviate poverty and social exclusion in some of the more disadvantaged neighbourhoods in the Bay area. For example, the Berkeley Youth Alternatives Garden aims to create leisure opportunities for children with a special children's garden, as well as earning opportunities for young people from low-income homes. Organic produce is sold to local retailers and in the Berkeley Farmers' Market. This activity has a dual purpose in offering job training as well as generating income for the participants. 
In cities all over the world drugs, crime, and poverty interact with devastating effects on the lives of young people. This is especially so in California where the crime and drugs problems are exacerbated by easy access to guns. The biggest gun shop in California is in Leandro, just south of Oakland with its high percentage of disadvantaged residents. Maylie Scott, with other women from the Buddhist Peace Fellowship, picketed this shop. To protest in this way is neither utopian nor idealistic. It is a way of reminding those who choose to forget, especially the lawmakers and state officials, that the privilege of citizenship comes with responsibilities for what happens in our communities.

The effect of guns and drugs on poor neighbourhoods in American cities has been devastating. Although the Bay area must be among the richest communities in the world social polarization is also very high, with "people of colour" suffering the greatest deprivation. Community gardens are now being used to develop alternatives for young people exposed to the drugs and crime economy. The Strong Roots Gardens in Oakland and Berkeley are examples of this. Melody Ermachild Chavis founded these gardens with neighbours from her East Bay neighbourhood. Melody is also an activist in the Buddhist Peace Fellowship. Strong Roots Gardens are gardens which offer job training, and earning opportunities to African-American and other socially excluded young people.

In San Francisco a very ambitious project of this type is the St Mary's Youth Farm. The farm is being created on about six acres of land and features biointensive food production along with habitat restoration and environmental education. The farm and garden now supply cheap organic vegetables to the residents of a nearby housing project and with the support of the Mayor's Office has been able to offer wages that are nearly double the minimum wage to young people after school hours and during school vacations. It also offers work and training opportunities to local young people who mostly come from the nearby housing project. The need to counter the local drug economy and its impact on teenagers of high-school age is very much part of the rationale for this project. The involvement of the local community in the Youth Farm is seen as essential for its success.

Another outstanding success story in the Bay area is that provided by the Garden Project founded by Cathrine Sneed, an African-American who started her first garden in San Mateo County Jail while she was a legal counsellor there. Cathrine Sneed's work with offenders is now internationally recognized (see Ferris et al. 200I). The Garden Project, in partnership with the Mayor's office in San Francisco, now maintains a garden in one of the poorest neighbourhoods in San Francisco. Ex-prisoners were also planting ten thousand trees in San Francisco. The success rate of this project, measured by non-return to jail within three years, is 75 per cent. The rate of pay is twice minimum wage. Part of the secret of this success resides in the fact that a living wage is only part of the story for African-Americans discharged from prison. The Garden Project also addresses issues of self-esteem that are equally important in overcoming a criminal record and the stigma of jail, especially 
for those exposed to virulent racism in the criminal justice system (Ladipo 200I).

\section{Healing and therapy gardens}

A growing, and not always recognized, dimension of the community gardening movement is the healing and therapy gardens. There were a number of these in San Francisco. This can be seen very clearly in San Francisco City in the AIDS Memorial Grove which was created in the famous Golden Gate Park. The AIDS Memorial Grove is a fifteen-acre wooded dell that has been especially landscaped so as to provide a place for those who have been touched in some way by AIDS and also as a memorial garden for those who have died of the disease since the ig8os. It has been maintained with voluntary donations and labour. The President of the USA and Congress conferred national public landscape status on the garden in I996. The effort to provide for and maintain this garden has contributed to overcoming the stigma that is still attached to the disease. Like the AIDS hospice movement, largely financed by voluntary contributions, it is a public expression of compassion.

Less high-profile, but in many ways just as effective, has been the creation of the Comfort Garden at the San Francisco General Hospital. The original aim of the garden was to pay tribute to the staff of the hospital who had died. The garden was offered as a memorial to their work over the years. The San Francisco General Hospital is a striking building. The garden was designed and planted by Alain Kinet, one of two gardeners employed at the hospital. This garden is now used by patients and staff, who can retreat there for peace and quiet. It can clearly be seen as making a substantial contribution to the healing role of an important city hospital in one of the poorest areas of the city. Alain Kinet and his colleague also had a vegetable garden, which supports a scheme for providing food at home to AIDS and other patients. Alain Kinet was an employee of the City Parks and Recreation Department. It seems to us that the way in which civic values are embodied in this garden and in how the garden is used make it very much a community garden, the community being the hospital itself. This is an example created from the 'bottom up'. Hospital managers can now be proud of this garden because of the initiative of members of the gardening staff (see Cooper-Marcus and Barnes 1995).

Healing and therapy gardens are becoming very much an important element in community care provision following the closure of large mental hospitals and the perceived need to treat many more people in the community. These gardens also offer rehabilitation programmes to people who have suffered barriers to full social inclusion. A good example of this is the Rubicon Centre in Richmond, California. Many, if not all, of those who benefit from the horticultural services offered by Rubicon suffer from mental illness or learning disabilities. An important dimension of healing gardens is that of restorative and quiet gardens, often provided by religious foundations, such as the Quiet Garden Movement (see Ferris et al. 200i; Spriggs et al. I998). 


\section{Neighbourhood pocket parks}

A new kind of civic park is emerging in cities where finance and resources for conventional parks and open spaces have been cut back in recent years. This is the neighbourhood pocket park. A good example can be found in Berkeley. The Halcyon Commons is in the South Berkeley neighbourhood. It is a striking example of a residential neighbourhood reclaiming land from the great twentieth-century 'encloser', the automobile. Halcyon is in a residential area that had become a favoured parking place for nearby businesses and shops. The residents, in collaboration with the City Planning Department, raised the money and contributed voluntary labour to create a small park where cars used to park. It is rather like a residential London Square but without a fence or gate. There is a children's playground, trees, shrubs and attractive flower beds, along with a Japanese Peace Gate. It is now a very attractive and accessible pocket park, open to public and residents alike. It is a genuine public space that exists as a result of civic initiative. The City of Berkeley now has a number of these parks.

\section{Ecological restoration}

Ecological restoration has combined with social objectives to provide another form of community garden. There are many urban areas where longestablished waterways have been enclosed in concrete culverts. Many of these are now being restored to something resembling their natural state. The Strawberry Creek Gardens and Park in Berkeley are an example. The creek itself has been partially restored to its natural state with voluntary labour and scientific expertise from the East Bay Conservation Corps. This creek flows from the famous botanical gardens above the University at Berkeley down to the Bay itself. It is in many ways a good example of creek (or river) restoration that could be copied elsewhere.

\section{Demonstration gardens}

A good example of a garden devoted to public education is the Garden for the Environment in San Francisco. This garden, like the St Mary's Youth Farm mentioned above, is managed by SLUG, the San Francisco League of Urban Gardeners. The function of this garden is to teach city residents about composting, organic gardening and water conservation. Another garden of this type is the Gill Tract Urban Farm on land owned by the University of California at Berkeley. While the primary purpose of this farm is to provide a site for research into sustainable agriculture it is also an organic farm that is used for adult education and youth employment. At the time of our visit in I997 the future of this farm was in doubt as there were proposals to build on some or all of the land. The campaigning organization "Food First" based in Oakland was hoping that it would be possible to find funds to acquire the land and take over and develop the educational project from the University of California. 


\section{Conclusion}

The research in the USA on community gardens was concerned with two broad questions. First, what policies would be effective in giving persuasive meaning to the social dimension of sustainability within the framework of Local Agenda 21? Second, in what ways might community gardens and green space policies in urban areas contribute to greater environmental justice?

In many cities in the USA, although by no means all, community gardening can be seen as the outcome of civil rights struggles of the ig6os and I97os. This is especially so inasmuch as they generated local and participative forms of neighbourhood-level politics. The community gardens have grown up in the wake of the abandonment of inner-city areas by the white majority and especially the major employers (see Bass Warner 1987). The middle classes have vacated the inner city to the so-called Edge City (Garreau I99I). At the same time service-sector enterprises and jobs have also migrated there. African-Americans and Hispanic people along with other "people of colour" have found themselves trapped in economically and environmentally damaged neighbourhoods (Bullard 1994; Gottlieb 1993). Around the San Francisco bay are the flatlands, the areas located near the old naval bases, docks, petrochemical refineries and former heavy manufacturing districts. These are the rustbelt places that were poisoned by toxic chemicals and illegal dumping of waste. Many of the community gardens are in these places and it is the poor and people of colour who are exposed to the greatest environmental risks. The community garden movement in the USA is, in part, one of the positive responses in the struggle to restore these damaged neighbourhoods to ecological and social health.

The information presented here is mainly concerned with the USA and, in particular, focused on California. Nevertheless, the Nottingham Garden Conference in 2000 demonstrated that these are global issues. There are many themes and issues that emerged in the USA that have become apparent in the Future of Allotments debate in the UK (HC 1998). The government has made it clear in their town planning policies that they expect 6o per cent of all new housing will be built on brownfield and inner-city sites. With the scarcity of urban land for new building there will be intense pressure on local government to develop on underutilized allotment sites. Higher urban densities might lead to a reduction in the amount of urban green space. This is precisely the issue in New York City where the City Council is claiming there is a shortage of land for housing and are closing community gardens (Ferris et al. 200I).

What we can say on the basis of our work to date is that urban green spaces and community gardens (allotments in Europe) can be very positively linked to the implementation of Local Agenda 2I and sustainability policies and at the same time used to promote environmental equity. There is considerable evidence that poor and disadvantaged people not only suffer from low incomes but many also have to live in environmentally degraded environments that are threatened by polluting industry and the consequences of toxic waste dumping. This is not simply a US experience but is now a global phenomenon (Sachs 1995; Beck 1992). 


\section{References}

Bass Warner, Jr, S. (1987), To Dwell is to Garden, Boston: North Eastern University Press.

Beck, U. (1992), Risk Society: Towards a New Modernity, London: Sage.

Bullard, R. D. (ed.) (I994), Unequal Protection; Environmental Fustice and Communities of Colour, San Francisco: Sierra Club Books.

Chavis, M. E. (I997), Altars in the Street: A Neighbourhood Fights to Survive, New York: Bell Tower.

Cooper-Marcus, C. and Barnes, M. (1995), Gardens in Healthcare Facilities: Uses, Therapeutic Benefits, and Design Recommendations, Center for Health Design, CA, USA.

Environmental Politics (I993), Vol. 2, No. 4, Winter, Special Issue, ed. Caroline Thomas, London: Frank Cass.

Ferris, J. S., Morris, M., Norman, C. and Sempik, J. (eds) (200I), People, Land and Sustainability: A Global View of Community Gardening, Nottingham: PLS.

Garreau, J. (1991), Edge City: Life on the New Frontier, New York: Anchor Books.

Gottlieb, R. (1993), Forcing the Spring: The Transformation of the American Environmental Movement, Covello, USA: Island Press.

HC (I998), The Future for Allotments, Report of the Environment Transport and Regional Affairs Committee, HC 560, London: House of Commons.

Ladipo, D. (2001), Imprisoned America, New Left Review, 7, Second Series, January/ February, London, UK.

Roddick, J. and Dodds, F. (I993), Agenda 2I's political strategy, Environmental Politics, 2, 4, Winter, London: Frank Cass.

Sachs, A. (1995), Eco-Justice: linking human rights and the environment. Worldwatch Paper 127, December, Washington DC.

Spriggs, N., Kaufman R. E. and Bass Warner, Jr, S. (I998), Restorative Gardens: The Healing Landscape, New Haven CT: Yale University Press.

Waters, A. (1996), Chez Panisse Vegetables, New York: HarperCollins. 
Copyright of Social Policy \& Administration is the property of Wiley-Blackwell and its content may not be copied or emailed to multiple sites or posted to a listserv without the copyright holder's express written permission. However, users may print, download, or email articles for individual use. 